\title{
as education of the oppressed
}

\author{
NC van Wyk \\ Ph. D. \\ Department of Nursing Science \\ University of Pretoria
}

"Health education tries to transfer the responsibility for health and wellbeing from the professional to the patient. The patient then has to decide whether he accepts this responsibility or not, since he cannot be forced into doing so ..."

\section{Abstract}

Paolo Freire's theory of critical thinking shows remarkable similarities to the principles supported by health education. In his capacity as Brazilian educationalist, Freire emphasized man's active participation in his own development. Without this active involvement, growth and development become quite impossible to attain.

Freire's theory is therefore generally well suited for use by those supporters of the currently emphasised actions of community empowerment and community involvement. Health education, and more particularly successful health education, is nothing more than community empowerment. It enables each individual, within a community, to take control of his/ her own life and well-being.

The health care professional cannot assign power and control to the individual; it can only be assumed by each individual within the community. In this regard it becomes evident that passive conveyance of the health care message, albeit from health care professional to individual recipient (in this instance to the patient), is of no use to the community, whereas active involvement of the individual displays greater success.

According to Paolo Freire, health education should focus on collective knowledge, the latter being the result of the group dynamics, produced by discussion on past experiences, and the analyses there-of. The professional guides these dynamic processes, not only to identify needs regarding health education, but also to assist in making decisions on health. Ultimately each individual will then experience the responsibility for his/her own health.

A discussion of the use of the theory of critical thinking, as well as the implementation there-of in practice, is provided.

\section{Opsomming}

Paolo Freire se teorie van kritiese denke toon merkwaardige ooreenkomste met die beginsels van gesondheidsvoorligting. In sy hoedanigheid as Brasiliaanse opvoedkundige het Freire die mens se aktiewe deelname in sy eie ontwikkeling beklemtoon. Sonder hierdie aktiewe deelname is groei en ontwikkeling bykans onmoontlik.

Paolo Freire se teorie is daarom besonder geskik vir gebruik deur die ondersteuners van gemeenskapsbemagtiging en gemeenskapsdeelname. Gesondheidsvoorligting en spesifiek suksesvolle gesondheidsvoorligting is niks meer as gemeenskapsbemagtiging nie. Dit stel elke individu binne ' $n$ gemeenskap in staat om beheer oor sy/ haar eie lewe en gesondheid te neem.

Die professionele gesondheidswerker kan nie mag en beheer aan die individu oordra nie, maar dit kan alleen deur die individu in die gemeenskap oorgeneem word. Die passiewe oordrag van gesondheidsinligting van die gesondheidspersoneel na die individu, in hierdie geval die pasiënt, is daarom van geen waarde nie, want aktiewe deelname dra tot die sukses van gesondheidsvoorligting by.

Volgens Paolo Freire moet gesondheidsvoorligting fokus op kollektiewe kennis as resultaat van groepdinamika. Dit word verseker deur bespreking en analise van vorige belewenisse. Die rol van die professionele persoon is daarop gerig om die groepdinamika te fasiliteer en nie om die behoeftes aan gesondheidsvoorligting te identifiseer nie. Hierdeur word verseker dat elke individu verantwoordelikheid vir sy/haar eie gesondheid sal aanvaar.

'n Bespreking van die gebruik van die teorie van kritiese denke en die implementering daarvan word verskaf. 


\section{Introduction}

Health education tries to transfer the responsibility for health and well-being from the professional to the patient. The patient then has to decide whether he accepts this responsibility or not, since he cannot be forced into doing so (Tones 1996: 12). However, patients cannot be expected to acquire behaviour necessary for health promotion, rather, they should be accompanied there-to during their development. The development of the patient may be compared to the development of critical awareness, as described in Paolo Freire's theory of The Education of the Oppressed (De Koning \& Martin 1996: 9). Paolo Freire, a Brazilian educationist, being excessively aware of the poverty and developmental shortfall of his people, in 1972 published a book entitled Pedagogy of the Oppressed (Roodt 1996: 315). He thereafter became known as a Third World activist and theorist (Roberts 1996: 94). Freire viewed teaching as a social process of change (Purdy 1997: 194). This viewpoint does however not only apply to developing societies (countries), since Freire saw the existence of a Third World in a First World and a First World in a Third World (Roberts 1996: 95). He specifically referred to differences in the level of social development that exists in all countries. Underdeveloped people may be found in the most developed of countries and vice versa. Wherever people with knowledge and developmental shortfalls are found, Freire's theory may be applied (Northway 1997: 740). He, himself, later applied his theory to traditionally disadvantaged groups, including women, children and the disabled (Northway 1997: 736).

\section{Problem-posing education}

Freire opposed situations where the transfer of knowledge occurred in the presence of passive learners. He called it banking education. Instead, he advocated problem-posing education which facilitated active learner participation. He specifically does not refer to problemsolving, since learners are not always capable of the latter (Roberts 1996: 97). Freire's viewpoint that education also implies social change, includes political aspects (ibid.). By encouraging people to critically analyse their own circumstances, including their poverty and disadvantaged social position, the process of conscientisation is achieved. This, in turn, enables them to become aware of their own capabilities in improving their circumstances (De Koning \& Martin 1996: 9). The process eventually leads to self-education and self-actualisation
(See Figure 1). It may, however, also lead to people rebelling against their disadvantaged position and the persons responsible for it, making education, according to Freire, political by nature (Roberts 1996: 100).

In contrast to what may be deduced from the above-mentioned discussion, Freire's theory is not exclusively reserved for working with politically suppressed and socially deprived persons or patients. Critical awareness of shortcomings may be advantageous to all persons (Maguire 1996: 33). These shortcomings may also be interpreted as being relevant to information regarding health. All patients may therefore be viewed as being disadvantaged, since they, as lay persons, do not possess the same knowledge as the professionals (Skelton 1994: 421). As with any other person, these patients, too, may be advantaged by critical awareness and thinking as described in Freire's theory (De Koning \& Martin 1996: 10). According to Freire, persons should critically view themselves, their experiences and their world before information may be transferred to them (Roberts 1996: 153). It also applies to the transfer of health education and health promotion. Simple transfer of information from one person to another does not necessarily motivate action. Health promotion cannot be successful unless behavioural changes are achieved (Boyd 1998: 189). Behaviour which is detrimental to people's lives, should be replaced by behaviour which promotes health and well-being, resulting in the development of a passive person, who has no control over his own health, into an active person who makes decisions and acts accordingly (Ewles \& Simnett 1996: 183).

The latter may be accomplished by focussing the accompaniment of the person towards critical awareness of himself, his abilities and his circumstances (see Figure 1), enabling the development of the person from a passive object to an active subject (Roodt 1996: 315). Such a person is not only critically aware of his potential and his abilities, but is also capable of transformation into a person who is able to accept responsibility for his own life. Selfactualisation will then be potentiated and it may even be made easier (Roodt 1996: 315). It implies that the person will be able to make use of the information and opportunities supplied by the health professional, within the context of health promotion, in order to attain self-actualisation and therefore also a high quality of life (Pender 1996: 19). Behavioural changes take place and health promotive behaviour is revealed. It is even followed by critical analysis, for which the patient takes responsibility (Flick et al 1994: 378). The patient now reaches the stage where he continuously evaluates his behaviour, seeks the help of health care professionals out of own initiative and uses their help in order to make the necessary adjustments.

\section{Critical \\ consciousness}

Critical consciousness, according to Shor, has four qualities, of which power awareness is one (De Koning \& Martin 1996: 8). The other three are: critical literacy, desocialisation and self-education.

\section{Power awareness}

The concept of power awareness not only holds relevance to Freire's theory of critical consciousness, but is also extremely important in health education. When a person does not believe in himself and does not realise that he is capable of behavioural change, or of sustaining such changes over prolonged periods of time, he cannot be motivated by a professional person. The person should therefore be his own locus of control (Kemm \& Close 1995: 111). Power awareness not only enables the person to become knowledgeable, but to also attach value to own experience and expertise (Breda et al 1997: 76) which, in turn, increases self-value. This approach continuously focuses on those abilities and experiences of the person which are already known. Thus, the person is continuously being empowered so that dependency and powerlessness are counteracted (Wang \& Burris 1994: 171), which may also imply that the course of an educational programme may be determined by the patients. The professional person will then act as facilitator only, thus, merely determining the structure of the programme. The latter may prove essential in providing the patients with security. It may also be possible, according to the followers of Freire's theory, for the learner, in this instance referring to the patient, to determine the content and the outcomes of his education (Rudd \& Comings 1994: 315). The latter is quite acceptable when one bears in mind that the approach being used is that of problem-posing (Roberts 1996: 149). During this aspect of the learning process, the professional person also holds a facilitating function.

In contrast to this highly liberal approach in education (patient education in this instance), it may be said that persons require a certain degree of literacy in order to become so actively involved. Freire's followers, however, managed to creatively overcome the problem of 


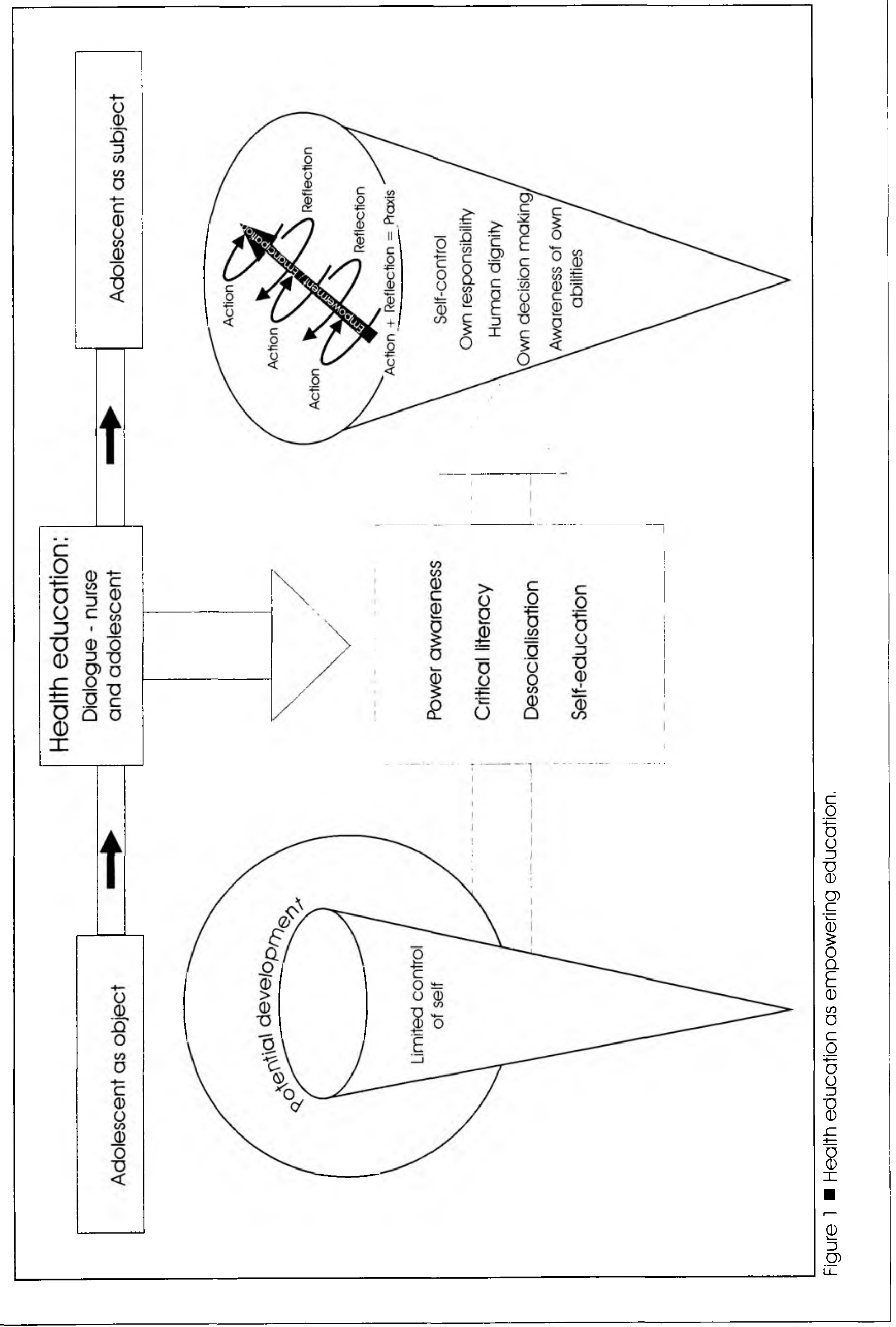


illiteracy by using cameras and photographs. They created a medium of communication by encouraging illiterate women and children to take photographs of situations which they viewed as being detrimental. These activities did not only increase their feelings of selfworth, but also enabled them to influence policy makers and others who, until then, had been making decisions on their behalf. The inability to read and write does not make women and children powerless. All persons, literate or illiterate, should be allowed to participate in the design and preparation of educational aids for use during their health education (Rudd \& Comings 1994: 315). Active involvement may thus be achieved, albeit it is not the only reason. It also serves as the only tangible proof that health education has taken place, and the patients can show concrete proof of their active involvement. Active involvement is of the utmost importance in health education, since health and illness are determined by the group or society. The professional person, as outsider, is unable to initiate the necessary behavioural change (Rudd \& Comings 1994: 313).

In the case of health education, a person takes charge of his own life, which includes responsibility for his own health and well-being. Freire's supporters view this process of taking charge as revolutionary. When this takes place, it is actually referred to as a brief revolutionary moment. Taking charge is a decision of free will, after which it should be strengthened and maintained by continual dialogue. In the case of health education, dialogue implies the exchange of expertise (Kendall 1992: 7). Expertise exists on both sides and can therefore not be transferred in a single direction. It enables empowerment, which is sustained by offering the previously disadvantaged knowledge, the opportunity for decision making and the use of available resources (Wang \& Burris 1994: 180).

\section{Critical literacy}

According to Freire, critical literacy, also referred to as critical thinking and reflection (Mayo 1996: 149), is the characteristic which distinguishes man from animal. Animals are unable to change their circumstances, since they are incapable of critical thinking. They merely adapt to their circumstances (Kendall 1992: 4). Through critical thinking, people can make decisions, and through making decisions, change their circumstances. The critical view that people have of their circumstances, is formed through dialogue with other people (Rudd \& Comings 1994: 315). These other people may, according to Freire, be persons who find themselves in similar circumstances in a specific community. It may also include the health educators who act as facilitators during the dialogue (Wallerstein \& Bernstein 1988: 382). The purpose of the dialogue is to critically view the circumstances and events which influence the people involved. All role-players in such a dialogue are considered as equals and colearners, including the professional facilitators, and the factors which are detrimental to health, as well as the reasons for the existence of these factors, are being discussed during the dialogue (Ford \& Profetto-McGrath 1994: 343). The critical thinking which takes place during such a dialogue, analyses the deeper meaning of the circumstances (De Koning \& Martin 1996: 8). Thus, the status quo is examined together with the reasons for it being maintained (See Figure 1)

The circumstances and other aspects to be discussed during the dialogue, are determined by the people who are to take part in it. The facilitator may however guide them to it. They may, for example, be requested to take photographs of their living conditions, as done by Wang \& Burris (1994: 171). The persons may also do it verbally, although charts, drawings, roll-play and even acting may be used (De Koning \& Martin 1996: 11). Sensitive and emotional aspects are mainly difficult to verbally convey to the group. The facilitator may never force a subject for discussion during a dialogue in which critical reflection is supposed to take place.

A formal lecture by the facilitator usually does not lead to critical reflection, although it may lead to a superficial discussion (Preston-Whyte \& Dalrymple 1996: 108). On the other hand, critical thinking does not occur spontaneously. Therefore, the dialogue group needs a facilitator who can guide them from discussing personal circumstances to discussing shared circumstances, and from superficial discussion to in-depth discussion (Wallerstein \& Bernstein 1988: 383). Thus, the professional person has a very definite role as facilitator. This role, it seems, has two functions, according to Freire and his supporters. Firstly, the process of dialogue has to be structured and, secondly, the information or knowledge the group requires for mutual reflection, has to be provided.

The following steps may be used in the structuring of the dialogue:

- Discussion of experiences and observations by the group.

- Description of the levels of the problem by the group.

- Sharing of similar experiences by members of the group.

- Questioning of reasons for the existence of the problem

- Development of a plan of action to address the problem.

- Reflecting on the effect of the plan of action. This step is known as the second circle of reflection (ibid.).

The dialogue and the critical reflection (steps 1 to 5) are followed by action and further reflection, which should again be followed by action. The process is repeated until the identified problem has been successfully resolved (Rudd \& Comings 1994: 315). The process of reflection and action is known as praxis and is a prerequisite for empowerment. Without action, however, reflection becomes worthless (Fulton 1997: 530).

The patient is not only encouraged into action by this, but also into the evaluation of his behaviour. Thus, he accepts responsibility for both his behaviour and the evaluation of his behaviour. If he is able to do this, he can also accept responsibility for further education, because he will be able to in future identify for himself when his behaviour is not to the benefit of his health. Through this process, the patient experiences that he has taken real possession of his health, because he will exists to be independent from health workers to a great extend. In future, he can use them as facilitators of health information. After he has established through reflection that his current behaviour is not favourable for his health, he can consult them for assistance with the identification of behaviour that will benefit his health condition. For example, the diabetic will know when the diet that he is following or the amount of exercise that he participates in, are not favourable to his condition anymore. As a result, he will be convinced of the necessity of adaptations. It may also happens that the person will himself make the necessary adaptations to his diet or exercise program, without contacting any health workers. Health literature, either in the form of books or on the Internet, are available freely.

\section{Desocialisation}

Desocialisation not only recognises the myths and values which have been conveyed to a person, but also questions them (De Koning \& M artin 1996: 8). With regard to health education and the nurse-patient relationship, it implies that the myth of patients necessarily being uninformed and ignorant, is being drawn into question. Through desocialisation, the patient becomes aware of the aspects that he is allowed to contribute to the relationship, as well as his right to decide on his own actions and life. The patient thus develops a trust in his own 
ability to control his personal and social life (Wallerstein \& Bernstein 1988: 380). Such a patient will no longer allow others to make decisions on his behalf. The process of reflection-action-and-furtherreflection breaks down the boundaries which have constrained him (Witt 1992: 150). The factors which contribute to the constrainment of the person, and his adherence to the myths and values handed down to him, are a lack of a positive self-image and a lack of a feeling of human dignity (ibid.). By critically evaluating his living environment, and by questioning the myths he grew up with, the patient becomes aware of his own abilities. That, in turn, breaks the cycle through which myths are spend and conveyed to the next generation (Fulton 1997: 530). According to Freire and his supporters, this implies that emancipating behaviour should be motivated whilst, at the same time, one has to guard against adaptation to harmful circumstances (Kendall 1992: 2). The person should therefore be motivated to develop from passivism and fatalism to activism and responsibility (Purdy 1995: 194).

The patient, through this process, becomes aware of his abilities and therefore also his dignity. Different from so many instances, the emphases is not placed only on the behaviour that harms his health, but on his own contribution to his health. Because his dignity is enhanced, he is motivated to greater participation. The patient now not only participates in decision making on his health, but also in the execution of the decisions. This results in the patient developing additional skills that will equip him to a greater extend to get even more involved in the advancement of his health. Thus, the diabetic will in future not only execute instructions with regard to his diet, but will be able to, under the leadership of the health workers, make adaptations to his diet. The result of this will be that the patient will develop trust in his own abilities to such an extend that he will become lesser and lesser dependent on the guidance of health workers to make adaptations to his diet, without putting his health in jeopardy. It makes it easier for him to keep to a certain diet, as he can now make adaptations himself, if the situation permits. The contribution of the health worker therefore decreases continuously, while, at the same time, the contribution of the patient increases. A situation thus develops where the patient can make decisions to a larger extend, with the health worker fulfilling a supportive role. The patient is made the master of his health through this situation.

\section{Self-education}

The transfer of information to patients often occurs during health education, because the nurse thinks that the patients require it. The information is usually rejected by the patients, not only because they do not perceive it as being useful and necessary, but also because it is often presented in such a way as to blame the patient (De Koning \& Martin 1996: 8). By continually reminding the patient that he contributes to his illness himself, his feeling of incompetence is confirmed. Such a person will obviously not be able to take control of his living conditions. He will not be able to change his behaviour in such a way as to be more health promotive, since such a change requires a positive selfimage and a strong belief in himself. On the other hand, Freire and his followers accentuate the advantages that collective knowledge holds for the individual. This should be developed, and the only way in which it may be accomplished, is by means of dialogue in which all role players are active participants. The process is known as empowerment education, since the learners empower themselves in order to take responsibility for their own health education (Ford \& Profetto-McGrath 1994: 343). They analyse their own living conditions, in order to ascertain whether these are health promotive or not, and take up the responsibility of obtaining the knowledge which they do not already have (Wallerstein \& Bernstein 1988: 379).

\section{Conclusion}

A participative professional person should take the responsibility for health education, in the place of the instructional professional person. Such a health worker will be able to give recognition for the things that the patient contributes to the nurse-patient relationship. These contributions include knowledge, skills and his perception of the circumstances (Muelensberg-Buskens 1996: 46). The patient will then no longer be the person without knowledge (power). This acceptance by the patient, and his expertise, then become the prerequisites for learning, during which new knowledge and skills may be mastered by him. Empowerment of the patient, and therefore also his community, requires much more from the health worker than the mere transfer of information regarding health and illness. It requires a horizontal relationship between health worker and patient and not a vertical relationship between expert and lay person (Chimere-Dan 1996: 33-34). The role of the health worker is therefore being lim- ited, and the role and responsibility of the patient expanded. True empowerment not only implies the allowance to participate, but rather to take over the responsibility for health and quality of life, which takes place within a relationship of mutuality and trust between the health worker and his patient. Through this, the health worker and the patient are placed on an equal and horizontal relationship to which both may contribute. 
Boyd, M.D. 1998. The teaching process. In Health Teaching in Nursing Practice: A professional model. Ed by Boyd, M.D; Graham, B.A; Gleit, C.J. and Whitman, N.I. Connecticut: Appleton and Lange: $183-200$.

Breda, K.L., Anderson, M.A., Hansen, L., Hayes, D., Pillion, C. \& Lyon, P. 1997. Enhanced Nursing autonomy through participatory action research. Nursing Outlook, 45(2): $76-81$.

Chimere-Dan, G. 1996. Community involvement in urban health programmes. Johannesburg: International Thomson Publishing.

De Koning, K. \& Martin, M. 1996. Participatory research in health: Setting the context, In Participatory research in health: Issues and experiences. Johannesburg: NPPHCN: 1 -18.

Ewles, L. \& Simnett, I. 1996. Promoting Health: A practical guide. London: Bailliere Tindall.

Flick, L.H., Reese, C.G., Rogers, G., Fletcher, P. \& Sonn, J. 1994. Building community for health: Lessons from a sevenyear-old Neighborhood - University partnership Health Education Quaterly, 21 (3): 369 - 380.

Flynn, B.C, Ray, D.W. and Rider, M.S. 1994. Empowering communities: Action research through healthy cities. Health Education Quaterly, 21(3): 395 - 405.

Ford, J.S. \& Profetto-McGrath, J. 1994. A model for critical thinking within the context of curriculum as praxis. Journal of Nursing Education, 33(8): 341 - 343.

Fulton, Y. 1997. Nurse's views on empowerment: A critical social theory perspective. Journal of Advanced Nursing, 26: $529-535$.

Kelly, B.R. 1995. Community-based research: A tool for community empowerment and student learning. Journal of Education, $34(8)$ : $384-386$.

Kemm, J. \& Close, A. 1995. Health promotion: Theory and practice. Theory and practice. London: MacMillan.

Kendall, J. 1992. Fighring back: Promoting emancipatory nursing actions. Advanced Nursing Science, 15(2): 1 - 15.

Maguire, P. 1996. Proposing a more feminist participatory research: Knowing and being embraced openly. In Participatory research in health: Issues and experiences. Johannesburg: NPPHCN: $27-39$

Mayo, P. 1996. Transformative adult education in an age of globalization: A Gramscion - Freirean synthesis and beyond. The Alberta Journal of Educational Research, XLII(2): 148-160.

Meulenberg-Buskens, I. 1996. Critical awareness in participatory research: An approach towards teaching and learning. In Participatory research in health: Issues and experiences. Johannesburg: NPPHCN: $40-47$.

Northway, R. 1997. Disability and oppression: some implications for nurss and nursing. Journal of Advanced Nursing, 26: $736-743$.
Pender, N.J. 1996. Health promotion in Nursing Practice. Third Edition. Connecticut: Appleton and Lange.

Preston-Whyte, E. \& Dalrymple, L. 1996. Participation and action: Reflections on community - based AIDS intervention in South Africa. In Participatory research in health: Issues and experiences. Johannesburg: NPPHCN: $108-118$.

Purdy, M. 1995. Humanist ideology and nurse education. Nurse Education Today, 17:192 - 195.

Roberts, P. 1996. The danger of domestication: A case study. International Journal of Lifelong Education, 15(2): 94-106.

Roberts, P. 1996. Critical literacy, breadth of perspective and universities: Applying insights from Freire. Studies in Higher Education, $21(2): 149-163$.

Roodt, M.J. 1996. "Participatory development": A jargon concept? In Reconstruction and development of people. Johannesburg: International Thomson Publishing Ltd: 312 - 323.

Rudd, R.E. \& Comings, J.P. 1994. Learner developed materials: An empowering product. Health Education Quaterly, $21(3)$ : 313-327.

Skelton, R. 1994. Nursing and empowerment: Concepts and strategies. Journal of Advanced Nursing, 19:415-423.

Tones, K. 1996. The anatomy and ideology of health promotion: empowerment in context. (In Health promotion Professional perspectives. Ed by Scriven, A. and Orme, J. London: MacMillan: 9 - 21).

Wallerstein, N. \& Bernstein, E. 1988. Empowerment education: Freire's ideas adapted to health education. Health Education Quaterly, 15(4):379-394.

Wang, C. \& Burris, M.A. 1994. Empowerment through Photo Novella: Porta of participation. Health Education Quality, 21(2): $171-186$

Witt, B.S. 1992. The liberating effects of RN-to-BSN education. Journal of Nursing Education, 31(4):149-155. 